\title{
DEGRADATION OF STANDARD DYES AND TEXTILE WASTEWATER AS A POLLUTANT MODEL USING GAMMA RADIATION
}

\author{
A. Sumartono \\ Centre For Application of Isotopes and Radiation Technology \\ National Nuclear Energy Agency (BATAN) \\ Cinere Pasar Jum'at PO.Box 7002 JKSKL, Jakarta 12070, Indonesia
}

\begin{abstract}
DEGRADATION OF STANDARD DYES AND TEXTILE WASTEWATER AS A POLLUTANT MODEL USING GAMMA RADIATION. A degradation and a decoloration of textile wastewater using ionizing radiation are already applied which some factors influence i.e. original wastewater, $\mathrm{pH}$, pollutant concentration, solubility and variation of polutant. A dyes standard had been treated using ionizing radiation and the mechanism degradation will be discussed. The percentage of the dye degradation about $90-99 \%$ at doses of 2-10 kGy. The degradation of textile wastewater using gamma radiation is was carried out at doses of $25 \mathrm{kGy}$. The combination of irradiation and the addition of coagulant caused the decoloration and the degradation of the textile wastewater.
\end{abstract}

Keywords : Dispers dyes, Basic dyes, Reactive dyes, Textile wastewater, Ionizing radiation

\section{INTRODUCTION}

The growth of the world population, the development of various industries, and the use of fertilizers and pesticides in modern agriculture have overloaded not only the water resources but also the atmosphere and the soil with pollutants [1]. In the last few decades the handling of wastewater appeared to be one of the most important. Textile industry which is one of the largest water consumer in the world, produces the wastewater comprising of various recalcitrant agents such as dye, sizing agents and dying aid. Therefore it has to be really concerned in releasing these types of wastewater to the environment. In the disposal of textile wastewater, color is of very important due to the aesthetic deterioration as well as the obstruction of penetration of dissolved oxygen and sun light into natural water bodies [2]. The sunlight penetration and reduction of dissolved of oxygen into natural water sources affects to aquatic life. The dye precursors and the degradation products of the dye are proven to be carcinogenic and mutagenic in nature.

In general, different types of dyes are used for colorization of textile in the dying process. The dyes (soluble or insoluble) that used in textile industry are synthetic and have a complex chemical structure and persist in nature. Therefore, they can not be degraded easily by ordinary treatments. Conventional method for eliminating dyes from the waste water include floculation with lime, activated charcoal adsorption and bio treatment. Lime treatment and charcoal adsorption generate solid wastes which require 
costly disposal methods. Biotreatment processes rely on indigenous soil microorganisms to degrade dye compounds. Since the synthetic dyes are usually resistant to aerobic biodegradation, this process is likely to be inefficient [2-3]. It was reported that ionizing radiation has the ability to reduce biological oxygen demand (BOD) and chemical oxygen demand (COD) to convert refractory compounds to a more oxidizable by biological or chemical agents, to destruct bacteria and to make the improvement in handling disposal of solids [4].

The objective of the study is to degrade the standard (anthraquinone and azo) dyes and textile wastewater as a model of pollutant using gamma radiation. Variation parameters i.e. the change of the spectrum, total organic carbon (TOC), the addition of coagulant, absorbed dose, variation of $\mathrm{pH}$ and radiation, and combination of radiation with the addition of coagulant will be discussed in this paper.

Previous researchers have reported that radiation induced decolouration and degradation of disperse, acid and reactive dyes, so that radiation technology could be an alternative method to solve the textile industries problem [6-12]. The radiation technique helps to solve environmental problems very efficiently, especially in the degradation of water pollutant.

Ionizing radiation can be used for the treatment of dye standards and textile wastewater effluents treatment. Radiation-induced decoloration and degradation of water soluble azo and anthraquinone dyes especially in the presence of oxygen during irradiation.

In this report some determining factors which can strongly influence the efficiency of the radiation-induced pollutant degradation are kind and energy of radiation, absorbed dose and dose rate, effect of pollutant concentration, influence of $\mathrm{pH}$, temperature influence, effect of oxygen and ozone, and effect of the molecular structure.

The research was carried out to degrade and decolour the dyes standard and textile wastewater as a model of pollutant using gamma radiation. The addition of coagulant, radiation, variation of $\mathrm{pH}$ and radiation, and the combination of radiation with the addition of coagulant were used to degrade and decolour the dyes standard and textile wastewater will be discussed in this paper.

\section{THEORY}

\section{Radiolysis of Water}

Radiation interaction between gamma rays with water will produce some species as described in the equation 1.

$$
\mathrm{H}_{2} \mathrm{O} \sim \mathrm{N} \mathrm{H}^{\bullet},{ }^{\circ} \mathrm{OH}, \mathrm{e}_{\mathrm{aq}}{ }^{-}, \mathrm{H}_{2} \mathrm{O}_{2}, \mathrm{H}_{2} \text { and } \mathrm{H}^{+}
$$


Mechanisms interaction of ionizing radiation with water will produce species $\left(\mathrm{H}^{+}, \mathrm{H}^{\bullet},{ }^{\bullet} \mathrm{OH}, \mathrm{e}_{\mathrm{aq}}{ }^{-}, \mathrm{H}_{2} \mathrm{O}_{2}\right.$, and $\left.\mathrm{H}_{2}\right)$ in the spur [5]. This species are the primer product that produced from radiolysis of water. These species will react with pollutant in a solution and they will degrade them. Those species are hydrogen atom $\left(\mathrm{H}^{\circ}\right)$, hydroxyl radical $\left({ }^{\circ} \mathrm{OH}\right)$, hydrated electron $\left(\mathrm{e}_{\mathrm{aq}}{ }^{-}\right)$, hydrogen peroxide $\left(\mathrm{H}_{2} \mathrm{O}_{2}\right), \mathrm{H}_{2}$ and hydrogen ion $\left(\mathrm{H}^{+}\right)$. From these products, the most reactive are hydroxyl radical, hydrated electron and hydrogen atom. In general, wastewaters contain dissolved oxygen, therefore $\mathrm{H}^{\bullet}$ and $\mathrm{e}_{\mathrm{aq}}{ }^{-}$can react with $\mathrm{O}_{2}$ to form an additional oxidizing species, perhydroxyl radical $\left(\mathrm{HO}_{2}\right)^{\bullet}$. The reactions are as followed :

$$
\begin{aligned}
& \mathrm{H}^{\bullet}+\mathrm{O}_{2} \longrightarrow \mathrm{HO}_{2} \\
& \mathrm{e}_{\mathrm{aq}}^{-}+\mathrm{O}_{2} \longrightarrow \mathrm{O}_{2}^{-} \\
& \mathrm{O}_{2}^{-}+\mathrm{H}^{+} \longrightarrow \mathrm{HO}_{2} \\
& \mathrm{HO}_{2}{ }^{-}+\mathrm{HO}_{2} \longrightarrow \mathrm{H}_{2} \mathrm{O}_{2}
\end{aligned}
$$

\section{Oxidative Destruction of Organic Compounds in Aqueous Solutions}

The most hydroxyl radical produced from radiolysis of water solution subsequently react with organic pollutant $(\mathrm{RH})$ in wastewater with the mechanisms as follows [4]:

$$
\begin{aligned}
& \mathrm{RH}+{ }^{\bullet} \mathrm{OH} \longrightarrow \mathrm{R}^{\bullet}+\mathrm{H}_{2} \mathrm{O} \\
& \mathrm{R}^{\bullet}+\mathrm{O}_{2} \longrightarrow \mathrm{ROO} \\
& \mathrm{ROO}^{\bullet}+\mathrm{RH} \longrightarrow \mathrm{ROOH}+\mathrm{R}^{\bullet} \\
& \mathrm{ROOH} \longrightarrow \mathrm{RO}+\mathrm{OH} \\
& \mathrm{RO}^{\bullet}+\mathrm{RH} \longrightarrow \mathrm{ROH}+\mathrm{R}^{\bullet} \\
& \mathrm{ROH}+2^{\bullet} \mathrm{OH} \longrightarrow \mathrm{R}^{\bullet} \mathrm{C}(\mathrm{OH}) \mathrm{H}+\mathrm{H}_{2} \mathrm{O} \\
& \mathrm{R}^{\prime} \mathrm{C}(\mathrm{OH}) \mathrm{H}+\mathrm{O}_{2} \longrightarrow \mathrm{R}^{\bullet}+\mathrm{CO}_{2}+\mathrm{H}_{2} \mathrm{O}
\end{aligned}
$$

The wastewater contain some complex substrate which is unknown and variable, therefore evaluation of any oxidation process can be calculate by measuring the total amount of organics and total oxidation equivalents in the wastewater.

There are two important general measurements on the wastewater are chemical oxygen demand (COD) and total organic carbon (TOC). The COD measures essentially all of the organic and inorganic oxygen demand except 
that of ammonia. The TOC measures the total amount of organic in the wastewater. Therefore the decrease in the TOC represents oxidation some of the organic material to $\mathrm{CO}_{2}$ and indicates the amount of completely destructive oxidation occuring in the system.

The degradation product such as acetic acid, oxalic acid, succinic acid etc described in equation 11 and 12 can be measured by high performance liquid chromatography (HPLC) system.

Studies on degradation and decoloration of disperse dyes (insoluble dyes) in water using irradiation was carried out using disperse dyes standard as a model pollutant i.e. Terasil Black CMS (TB CMS), Terasil Red 4G (TR 4G), Terasil Golden Yellow (TGY) and Terasil Blue BGE (TB BGE). The dyes were insoluble in water but completely soluble in methanol and chloroform, indicating that they are non-ionic subtances. The TB CMS, TR 4G, and TGY are commercial azo dyes and TB BGE is a commercial anthraquinon dye.

\section{EXPERIMENTAL METHODS}

\section{Reagents}

$\mathrm{Al}_{2}\left(\mathrm{SO}_{4}\right)_{3}, \mathrm{NH}_{4} \mathrm{Fe}\left(\mathrm{SO}_{4}\right)_{2}$ as coagulant, standard azo dyes as commercial name i.e : Terasil Black CMS (TB CMS), Terasil Red 4G (TR 4G), Terasil Golden Yellow (TGY), and anthraquinone dye: Terasil Blue BGE (TB BGE). Standard basic, direct, and reactive dyes are Maxillon Blue (MB), Direct Red (DR) and Cibacron Violet (CV), respectively. Samples of dyes waste water were taken from the effluent of textile industry of PT.Unitex, Bogor Indonesia in four different times.

\section{Experimental Design}

The samples from PT Unitex Bogor were taken four times from the effluent at different time, namely A, B, C and D, and one sample from out let, E. Irradiation was done using cobalt- 60 gamma rays at room temperature with various dose $0-30 \mathrm{kGy}$. The dose rate of $5 \mathrm{kGy} / \mathrm{h}$ was determined by Fricke dosimeter. During irradiation oxygen was bubbled through a porous plate at the bottom of the reaction vessel.The absorbance and the $\mathrm{pH}$ of the solution were measured by HP 8453 spectrophotometer uv-vis and Methrohm $620 \mathrm{pH}$-meter, respectively. The degradation products were determined by a High Pressure Liquid Chromatography (HPLC LC 5A0) using uv detector and Shodex Pax column. The experiment was performed at the Center For Application of Isotopes and Radiation Technology, BATAN. 


\section{RESULTS AND DISCUSSION}

\section{Degradation of Anthraquinone and Azo Dyes Using Ionizing Radiation}

as a Pollutant Model

\section{Disperse Dyes (Insoluble Dyes)}

The TB CMS, TR 4G and TGY are commercial azo dyes and TB BGE is a commercial anthraquinone dye. Figures 1, 3, 5 show the changes of TB CMS, TR 4G and TGY after irradiation in oxygen-saturated condition. After irradiation, the intensity of the main absorption decreased gradually as the dose increased. These intensity decreases are obviously due to the destruction of conjugated system of the dyes molecules by the attack of $\mathrm{OH}$ radicals. After irradiation, when concentrated nitric acid was added to reduce the $\mathrm{pH}$ to around 1 and the solution was kept for two days, the upper layer of the irradiated sample became clear and precipitated was occurred.

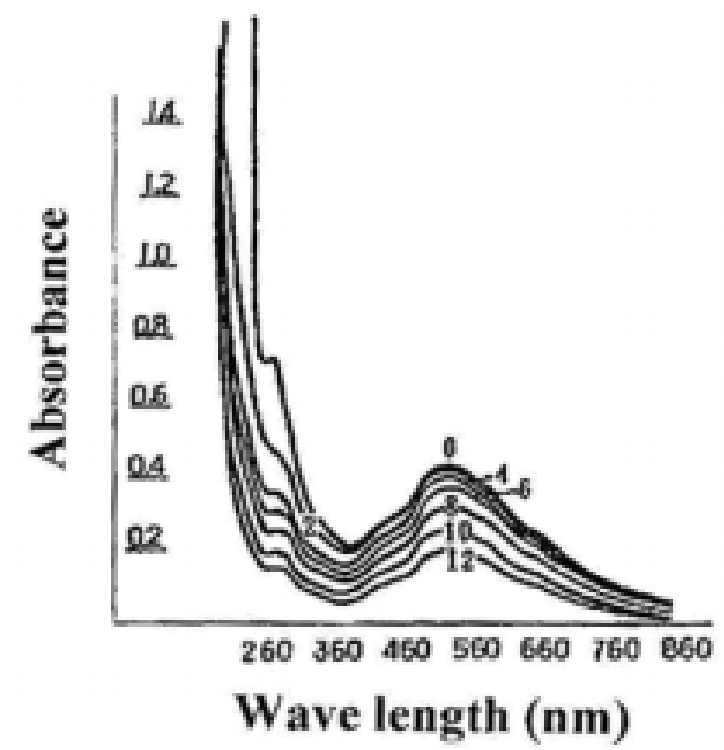

Figure 1. Absorption spectra of irradiated TB CMS in $\mathrm{O}_{2}$ bubbling solutions $(0,2,4,6,8,10$ and 12 represent the dose in $\mathrm{kGy})$.

Degree of precipitation was determined by measuring the spectra of the upper layer as shown in Figures 2, 4 and 6. The main absorption decreased markedly, especially at doses above 6,12 and $8 \mathrm{kGy}$ for TB CMS, TR 4G and TGY, respectively, while another peak appeared at $295 \mathrm{~nm}$ sharply for all doses (See also Figure 9 for TB BGE solutions). 


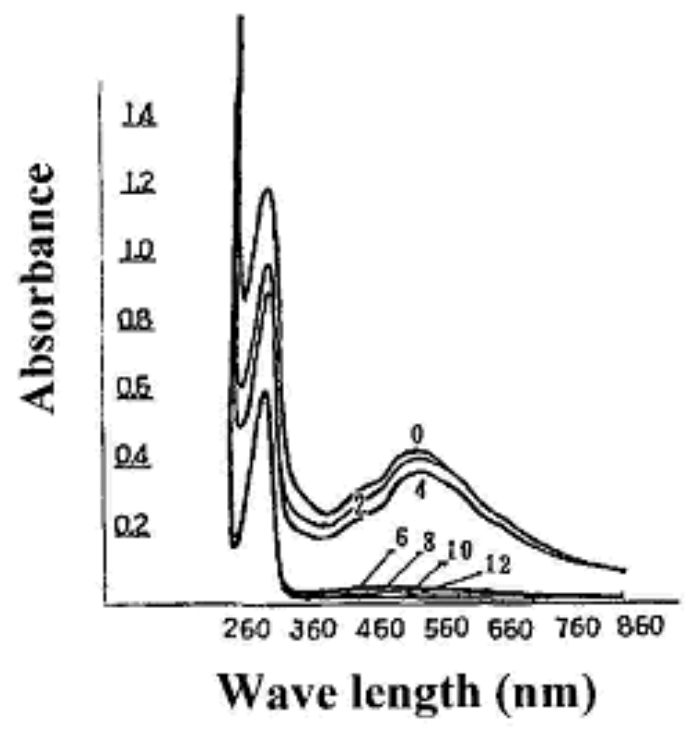

Figure 2. Absorption spectra of irradiated TB CMS in $\mathrm{O}_{2}$ bubbling solutions $+\mathrm{HNO}_{3}(0,2,4,6,8,10$ and 12 represent the dose in $\mathrm{kGy})$.

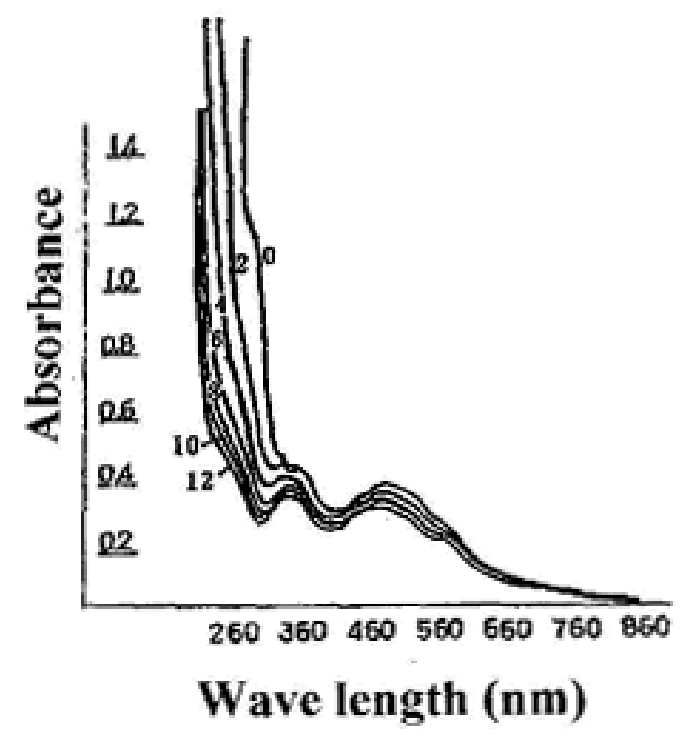

Figure 3. Absorption spectra of irradiated TR $4 \mathrm{G}$ in $\mathrm{O}_{2}$ bubbling solutions $(0,2,4,6,8,10$ and 12 represent the dose in $\mathrm{kGy})$. 
The changes of total organic carbon (TOC) of TB CMS, TR 4G and TGY solution irradiated in oxygen-saturated condition are shown in Figure 4. In oxygen saturated solution, the TOC content decreased slowly at doses below $6 \mathrm{kGy}$ for TB CMS, then decreased rapidly at doses above $6 \mathrm{kGy}$. But for TR 4G the TOC content decreased steadily with dose especially in nitric acid added solution. These results correspond to the change of absorption spectra of TR 4G as illustrated in Figure 4. The TOC content of TGY did not change much either after irradiation or after the addition of nitric acid. This fact does not correspond to the results of its absorption spectra measurements (Figure 6) which may be caused by the increasing of insoluble components from collloidal particles of the disperse dye due to irradiation [6-7].

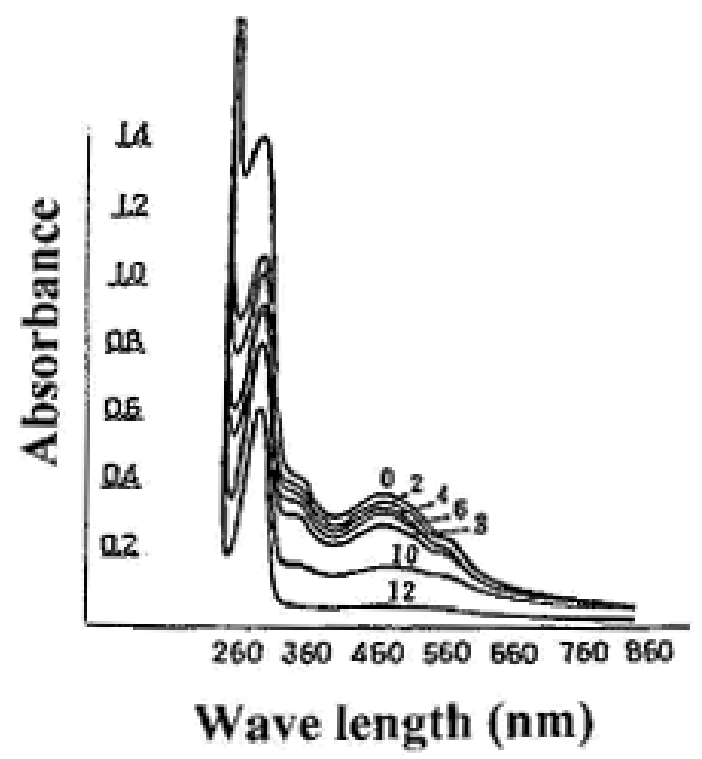

Figure 4. Absorption spectra of irradiated TR $4 \mathrm{G}$ in $\mathrm{O}_{2}$ bubbling solutions $+\mathrm{HNO}_{3}(0,2,4,6,8,10$ and 12 represent the dose in $\mathrm{kGy})$. 


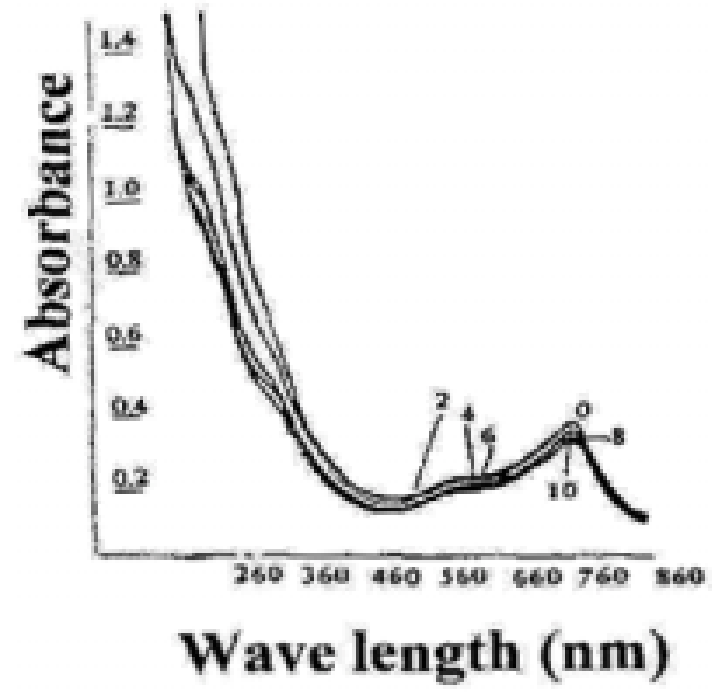

Figure 5. Absorption spectra of irradiated TGY in $\mathrm{O}_{2}$ bubbling solutions $(0,2,4,6,8,10$ and 12 represent the dose in $\mathrm{kGy})$.

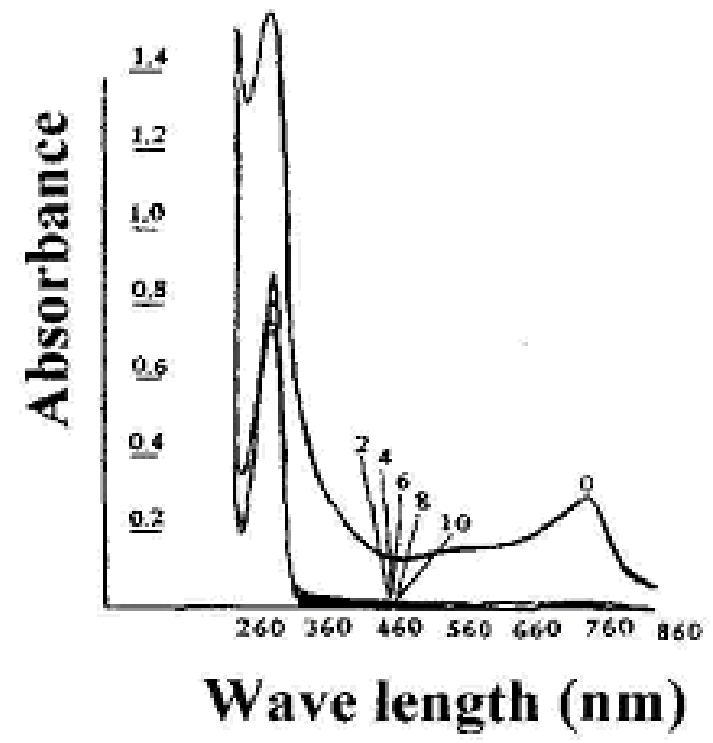

Figure 6. Absorption spectra of irradiated TGY in $\mathrm{O}_{2}$ bubbling solutions $+\mathrm{HNO}_{3}(0,2,4,6,8,10$ and 12 represent the dose in $\mathrm{kGy})$. 


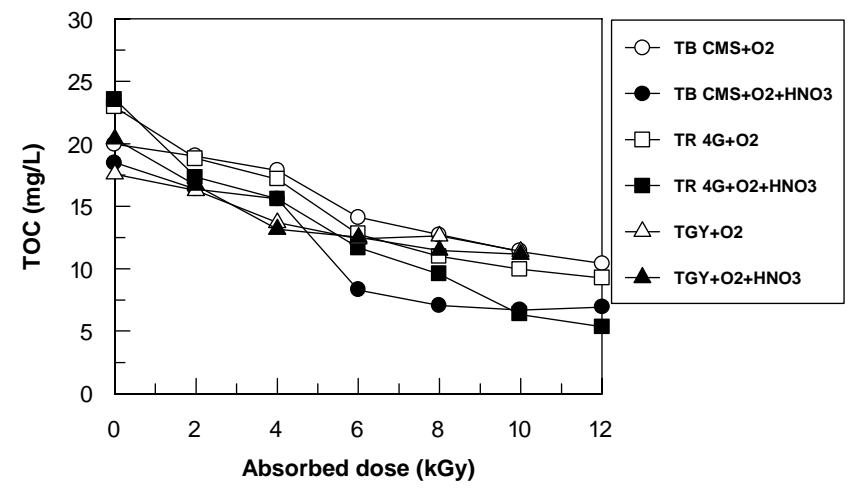

Figure 7. The Measurement of total organic carbon (TOC) and the effect of nitric acid on TOC changes in TB CMS, TR 4G and TGY.

Figure 8 shows the spectra change of irradiated TB BGE in oxygen bubbling solutions. After irradiation, the intensity of the main absorption decreased slightly with dose. However, after irradiation when nitric acid was added and settled for two days, precipitation occurred even at low dose as shown in Figure 9. These results suggest that chemical state of the surface of dye particles was changed by irradiation [6-7].

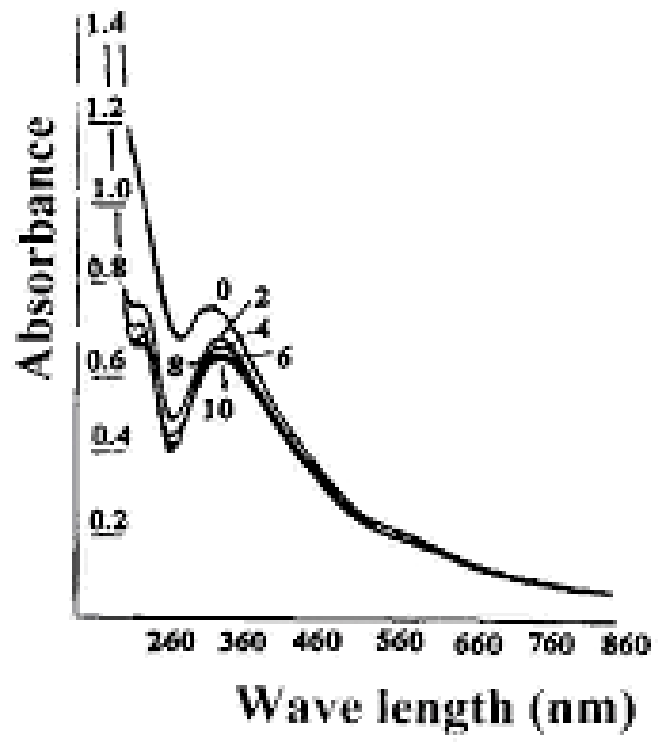

Figure 8. Absorption spectra of irradiated TB BGE in $\mathrm{O}_{2}$ bubbling solutions $(0,2,4,6,8$, and 10 represent the dose in $\mathrm{kGy})$. 


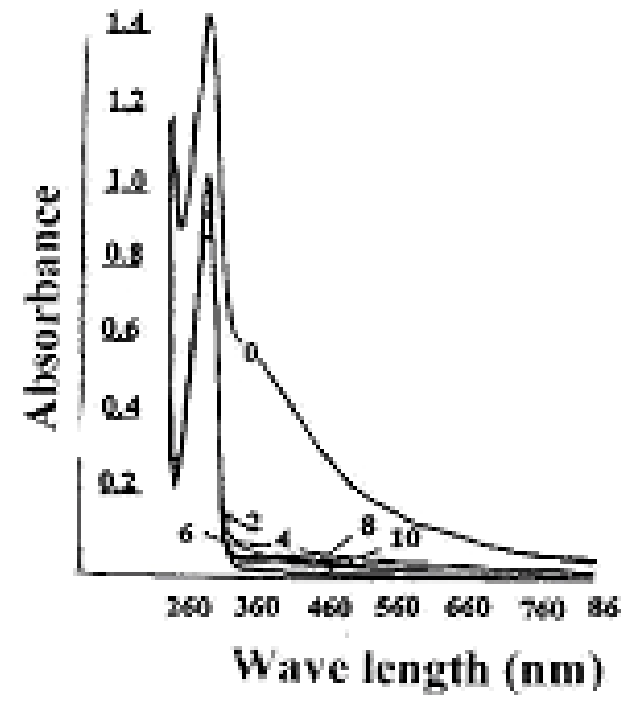

Figure 9. Absorption spectra of irradiated TB BGE in $\mathrm{O}_{2}$ bubbling solutions $+\mathrm{HNO}_{3}(0,2,4,6,8,10$ and 12 represent the dose in $\mathrm{kGy})$.

In general, two important factors in measurements waste water are chemical oxygen demand (COD) and total organic carbon (TOC). The COD measures essentially all of the organic and inorganic oxygen demand except that of ammonia. On the other hand, the TOC measures the total amount of organic carbon in the wastewater. Therefore the decrease in the TOC represents oxidation of some of the organic material to $\mathrm{CO}_{2}$ and thus indicates the amount of completely destructive oxidation occuring in the system. Figure 7 shows the change in TOC content in oxygen-saturated of TB BGE solutions due to irradiation and the addition of nitric acid after irradiation. The TOC content did not change much after either irradiation or the addition of nitric acid. The fact does not correspond to the results of its absorption spectra measurements (Figure. 5). This is probably due to increase of soluble components from colloidal particles of the disperse dye after irradiation.

The structures of the two disperse dyes are different as TB BGE is anthraquinone with an aromatic ring that is difficult to degrade using gamma radiation. On the other hand TB CMS has $\mathrm{N}=\mathrm{N}$ bond that is weak and easy to degrade. The same results have been also reported by Suzuki et.al [15] where the decoloration degree of soluble azo dye at $1 \mathrm{kGy}$ was almost $100 \%$, while that of soluble anthraquinone dye at $1 \mathrm{kGy}$ was only $50 \%$. After the addition of nitric acid, the phenomena of both disperse dye solutions were slightly different. Sedimentation occurred at higher dose for azo dyes but for antraquinone dyes occurred at lower dose. This phenomena is also influenced 
by the shape and the length of molecules. Anthraquinone dyes has thin shape, so neutralization and aggregation occurred easily at a low dose, while azo dye which is rather thick in shape, required a higher dose for degradation [6-8].

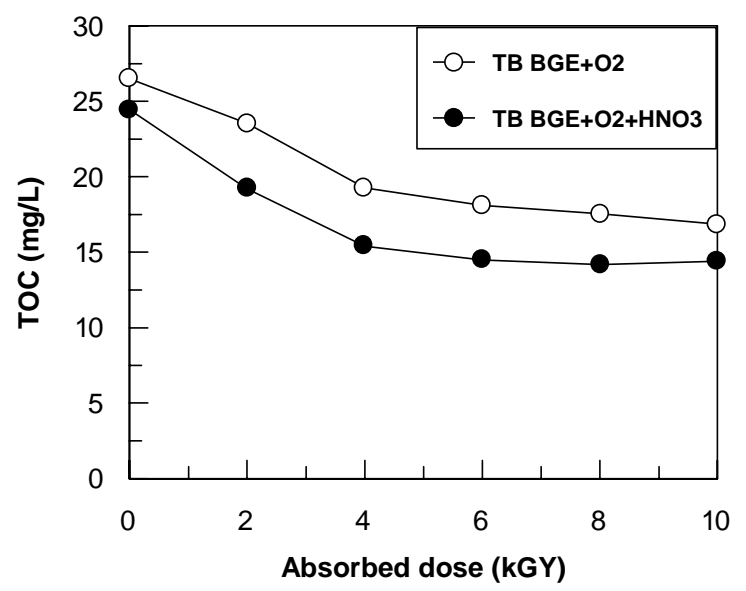

Figure 10. The Measurement of Total Organic Carbon (TOC) and the effect of nitric acid on TOC changes in TB BGE.

\section{Water Soluble Dyes}

Studies on degradation and decoloration of soluble dyes in water using irradiation was carried out using soluble dyes standard as a model pollutant i.e. basic, direct and reactive dyes. The basic dye is maxillon blue (MB), the direct dye is direct red (DR), and the reactive dye is cibacron violet $(\mathrm{CV})[9-11,13]$.

Figure 11 shows the spectra change of irradiated maxillon blue in oxygen bubbling solutions. At dose of $4 \mathrm{kGy}$ the percentage of degradation was achieved $100 \%$, in this condition the color change from blue into a decolored solution. maxillon blue could be degraded using gamma radiation at low dose ( $4 \mathrm{kGy}$ ), because this dye is soluble in water. Most of the soluble dyes could be degraded easily at low dose [15]. 


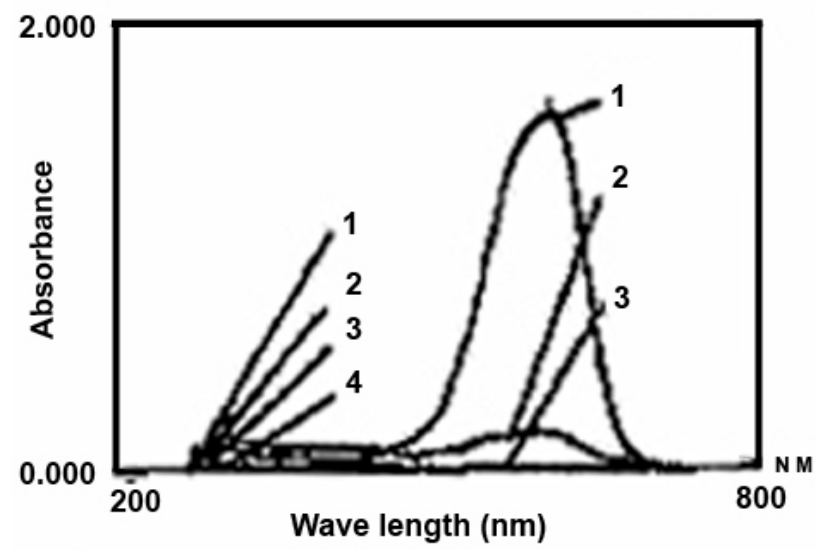

Figure 11. Absorption spectra of irradiated $\mathrm{MB}$ in $\mathrm{O}_{2}$ bubbling solutions $(1,2,3$, and 4 represent the dose in $\mathrm{kGy})$

Cibacron violet solution shows a clear absorption at $281 \mathrm{~nm}$ and $550 \mathrm{~nm}$ in the UV-VIS spectra as shown in Figure 12. The former absorption is considered to be the substituted aromatic rings and the latter can be assigned to conjugated system of the dye molecules. After irradiation at dose of $2 \mathrm{kGy}$ the intensity of the $550 \mathrm{~nm}$ decreased sharply. The degradation could be acvieved at dose of $10 \mathrm{kGy}$ at this condition the percentage of degradation almost $100 \%$.

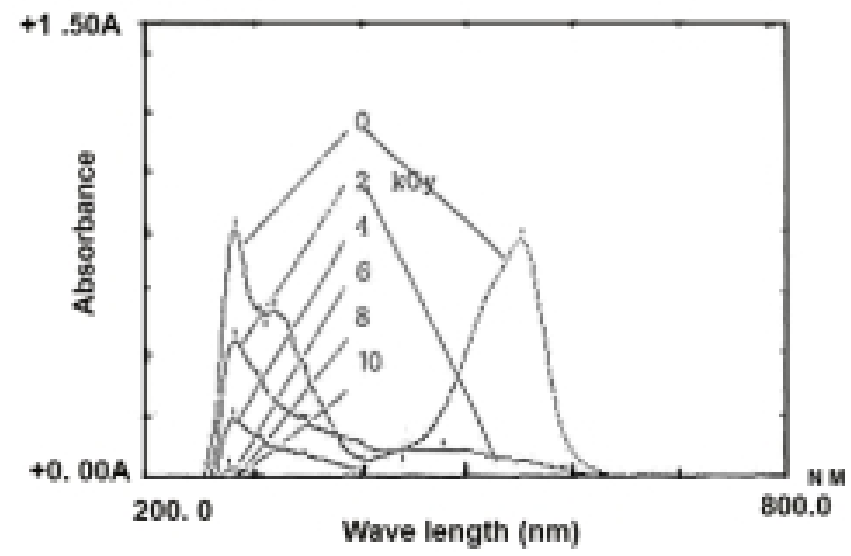

Figure 12. Absorption spectra of irradiated $\mathrm{CV}$ in $\mathrm{O}_{2}$ bubbling solutions $(0,2,4,6,8$, and 10 represent the dose in $\mathrm{kGy})$. 
Direct red shows a clear absorption at $528 \mathrm{~nm}$ and weak absorption at 288 and $372 \mathrm{~nm}$ (Figure 13). The 528 and $372 \mathrm{~nm}$ are assigned to be azo conjugated system and auxochromic effect of (-NH-CO-NH-) respectively. The $288 \mathrm{~nm}$ is substituted aromatic ring. At dose of $1 \mathrm{kGy}$ the red color has change into decolored solution. The decreased in intensity are obviously due to the attack of $\mathrm{OH}$ radical into azo group. At dose of $3 \mathrm{kGy}$ the percentage degradation is $99 \%$ in the UV area. This results indicated that the structure of the dye molecules already degraded. The degradation mechanisms of the dye can be explain as follow [15]:

$$
\begin{aligned}
& \mathrm{Z}+{ }^{\circ} \mathrm{OH} \longrightarrow \mathrm{ZOH} \quad \text { (decolored product) } \\
& \mathrm{Z}+{ }^{\circ} \mathrm{OH} \longrightarrow \mathrm{ZOH}^{\prime} \quad \text { (colored product) }
\end{aligned}
$$

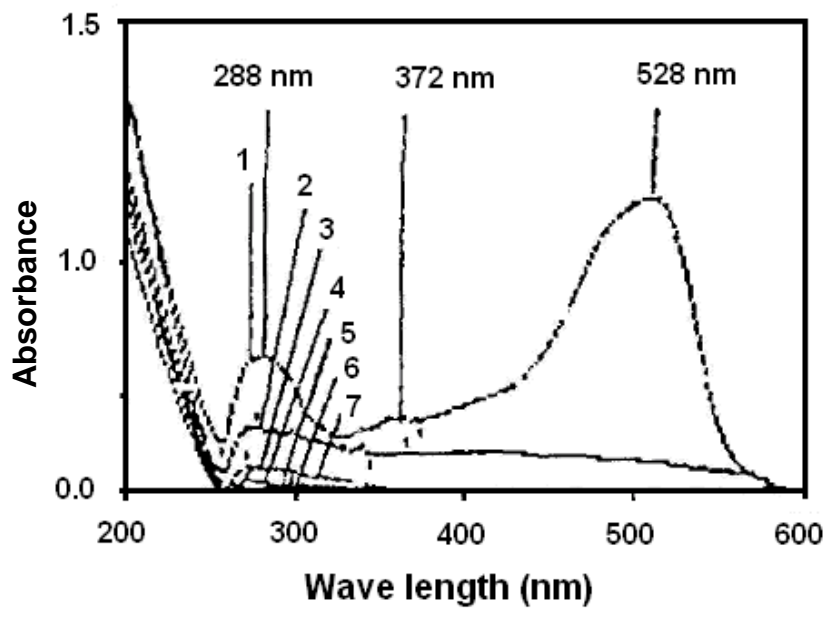

Figure 13. Absorption spectra of irradiated Direct Red in $\mathrm{O}_{2}$ bubbling solutions ( $1=0 \mathrm{kGy} ; 2=0.5 \mathrm{kGy} ; 3=1 \mathrm{kGy} ; 4=1.5 \mathrm{kGy}$; $5=2 \mathrm{kGy} ; 6=3 \mathrm{kGy}$ and $7=4 \mathrm{kGy})$

\section{Degradation of Textile Wastewater Using Ionizing Radiation}

Sample of dyes wastewater were taken from the effluent of textile industry of PT Unitex Bogor at a certain time and labelled as A, B, C and D. One sample was taken from the outlet of the wastewater process (E). Preparation of these samples were carried out by the addition of coagulant, iradiation without the addition of coagulant, combination irradiation and coagulant and variation of $\mathrm{pH}$ before irradiation. From the results it is suggested that some determining factors can strongly influence the efficiency 
of the radiation-induced pollutant degradation as ilustrated in Table.1 (1). Figure 14. shows the textile wastewater spectra that easily degraded at dose of $4 \mathrm{kGy}$ and $\mathrm{pH}$ 3. From the results it is assumed that the sample containing some soluble dyes. SUZUKI et.al reported that soluble dyes could be degraded at low dose. This is indicated that the sample may containing some dyes that soluble in water.

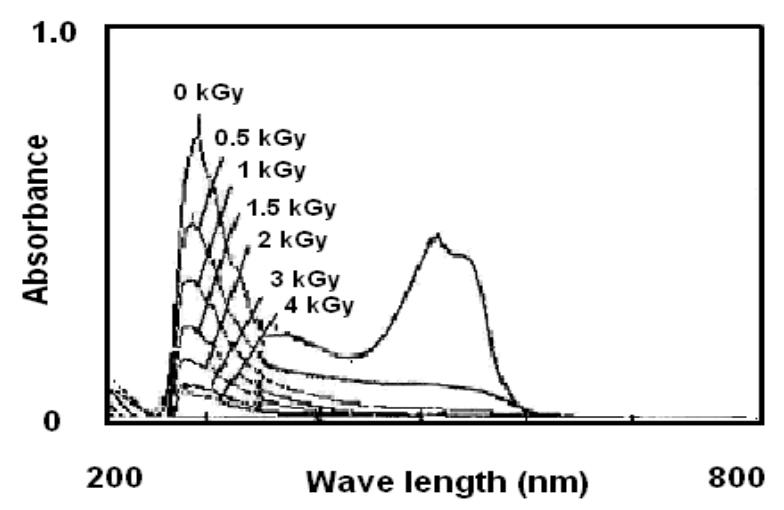

Figure 14. Spectra of textile wastewater after irradiation at $\mathrm{pH} 3$ in $\mathrm{O}_{2}$ bubbling solutions.

Table 1. Important experimental factors determining the efficiency of radiation-induced pollutant degradation [1].

\begin{tabular}{|c|l|}
\hline No & \multicolumn{1}{|c|}{ Factors } \\
\hline 1 & Kind and energy of radiation, absorbed dose and dose rate \\
\hline 2 & Effect of pollutant concentration \\
\hline 3 & Influence of pH \\
\hline 4 & Temperature influence \\
\hline 5 & Effect of oxygen and ozone \\
\hline 6 & Synergistic effect of radiation, $\mathrm{O}_{3}$ and $\mathrm{TiO}_{2}$ \\
\hline 7 & Effect of the molecular structure \\
\hline 8 & $\begin{array}{l}\text { Application of pulse radiolysis technique as an aid for better understanding of the } \\
\text { reaction mechanisms and hence for optimizing the degradation efficiency }\end{array}$ \\
\hline
\end{tabular}

Figure 15 shows the spectra of textile wastewater that has strong absorption at $291 \mathrm{~nm}$ and weak absorption at $530 \mathrm{~nm}$. These waste could be degraded after the $\mathrm{pH}$ was adjusted into $\mathrm{pH} 3$ with dose up to $30 \mathrm{kGy}$. The maximum degradation of this sample was obtained to be $85 \%$. From these results it is assumed that this sample may contain some insoluble dyes i.e disperse dyes, certain surfactant and inorganic additive due to the insolubility of the dye in water [7]. 


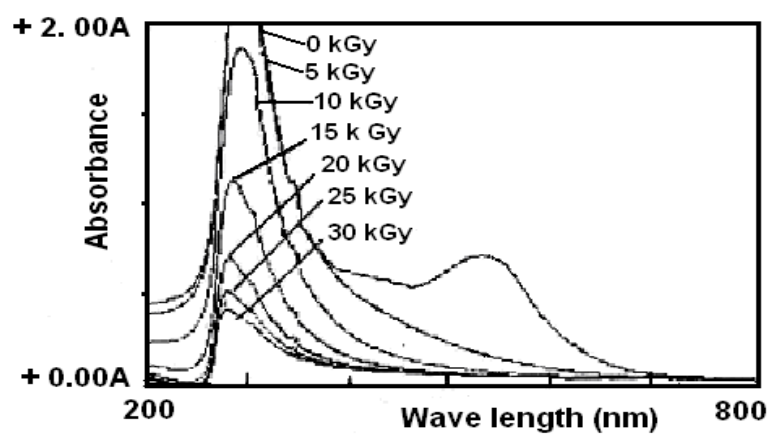

Figure 15. Spectra of textile wastewater after irradiation at $\mathrm{pH} 3$ in $\mathrm{O}_{2}$ bubbling solutions.

Experiment of sample D was carried out by combining radiation and addition of coagulant. Sample D has strong absorption at $282 \mathrm{~nm}$ in the UV region and slight shoulder at 345 and $454 \mathrm{~nm}$. First, $\left[\mathrm{Al}_{2}\left(\mathrm{SO}_{4}\right)_{3}\right]$ was added into sample D as a coagulant, furthermore the sample was settled for four days Subsequently, the upper layer was taken out and irradiated at doses of 0-25 kGy. Figure 16(a) shows the spectrum of original sample D before the addition of coagulant. Figure 16(b) shows the spectrum of sample D after the addition of coagulant and irradiated at dose of $25 \mathrm{kGy}$. The intensity in the visible region decreased clearly after addition of coagulant but the intensity of the spectrum in the UV region hardly to decrease as shown in Figure 16(b) (curve $0 \mathrm{kGy}$ ). After irradiation at dose of $25 \mathrm{kGy}$ the intensity in the UV region decreased markedly Figure 16(b) (curve $25 \mathrm{kGy}$ ). The intensity in the uv region is due to the aromatic rings from the dye molecules which is hard to degrade. These decreases in intensity are obviously due to the destruction of the aromatic rings of the dye molecules by attack of $\mathrm{OH}$ radicals that formed from radiolysis of water The percentage degradation after treatment with combination of addition coagulant and radiation could be achieved $84.3 \%$

This results then compare with the sample that taken from outlet as shown in Figure 16(b) (curve out let). By comparing the absorbance of sample outlet and sample D, it is seen that the intensity of the absorbance closed to each other. From the results above it is suggested that combination of radiation and coagulation could be used as an alternative method to treat textile wastewater to get better achievement. 


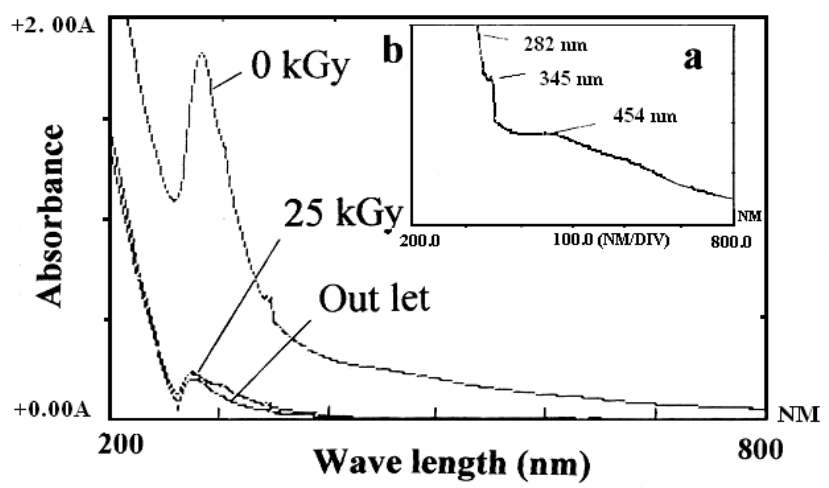

Figure 16. Spectra of sample D, (a) before the addition of coagulant and non-irradiated, (b) after the addition coagulant and irradiated at dose of $25 \mathrm{kGy}$.

\section{Mechanism Azo Dyes}

Degradation of the dye molecules is induced by the reaction with oxidative species from water radiolysis[3,14]. The oxalic acid might be formed by the oxidation of benzene which is generated by the attack of oxidative species such as hydroxyl radicals on the dye molecules (Figures 17 and 18). The $\mathrm{OH}$ radicals attack the azo linkage-bearing carbon (C-4) of a hydroxy or amine-substituted ring. The resulting $\mathrm{OH}$ adduct breaks down to produce phenildiazene and phenoxy radical. Phenildiazene is extremely unstable, $\mathrm{OH}$ or molecule oxygen can readily oxidize it by one electron to yield a phenildiazene radical, (Figure 11). The latter intermediate is also unstable and cleaves homolytically to generate a phenyl radical and molecular nitrogen. The phenyl radical might abstract a hydrogen radical to produce benzene. Nickelsen proposed the oxidation of benzene into carboxylic acid, such as oxalic acid through the formation of mucondialdehyde (Figure 18). 


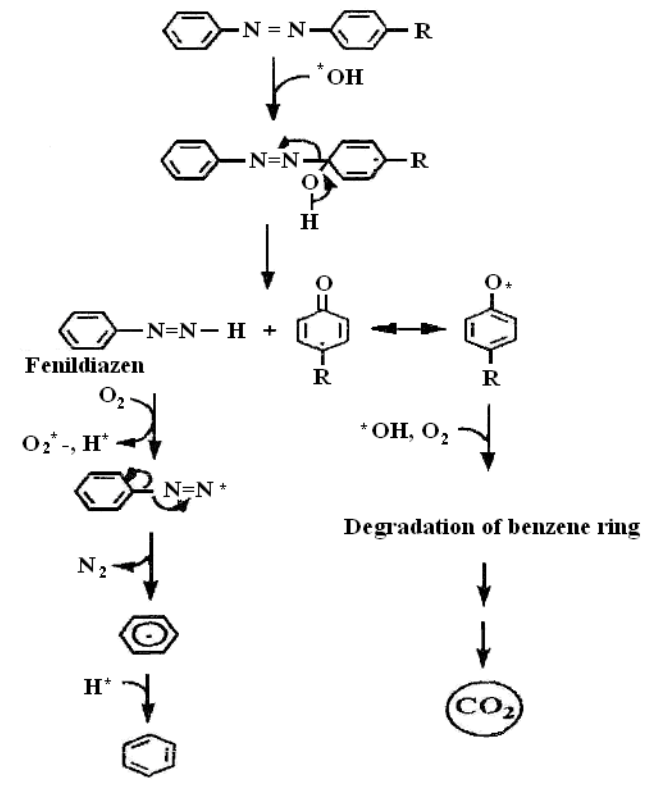

Figure 17. The formation of benzene from azo dye [3].

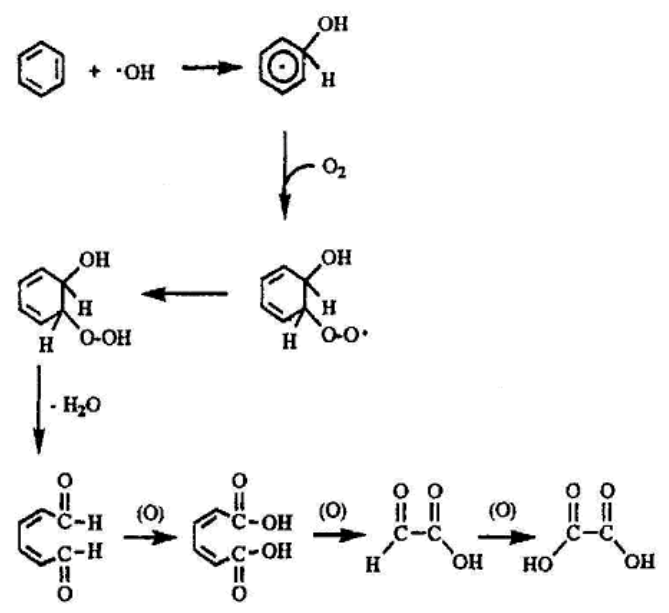

Figure 18. The formation of oxalic acid from benzene [14]. 
The degradation product of reactive dye cibacron golden yellow was analysed using high performance liquid chromatography (HPLC). The retention time of the sample was compared to that of organic standard. Figure 19 shows the chromatogram of irradiated of cibacron golden yellow at $10 \mathrm{kGy}$, it has the retention time at 4.292 and 7.413 minute. Chromatogram organic acid standards have retention time at 4.257 (oxalic acid), 7.383 minute (succinic acid), 8.223 minute (formic acid), 8.862 (acetic acid), and 10.598 (propionic acid) (Figure 20). By matching these two chromatogram it is assumed that degradation product of cibacron golden yellow are oxalic acid and succinic acid.

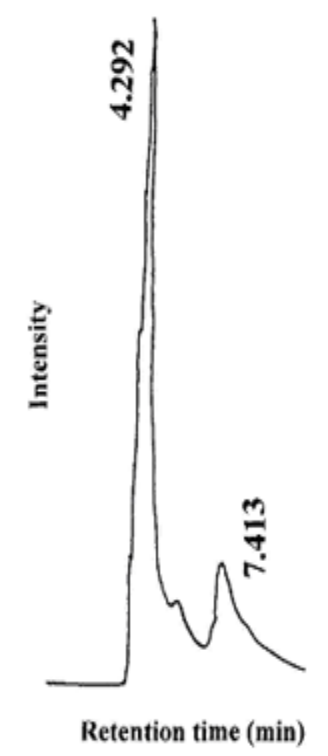

Figure 19. Chromatogram of irradiated cibacron golden yellow $10 \mathrm{kGy}$. 


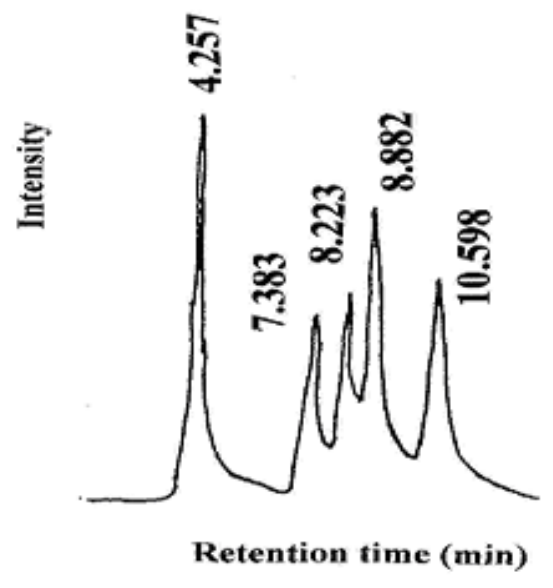

Figure 20. Chromatogram od carboxylic acids standard oxalic acid (4,257 min), succinic acid (7,383 $\mathrm{min})$, asetic acid $(8,862 \mathrm{~min})$ and propionic acid (10.598 min).

\section{CONCLUSION}

Decoloration and degradation of dye standards and textile wastewater can be done by irradiation, but the required dose varies with the type of the dye and the structure of the molecules. The addition of coagulants in textile wastewater treatment using gamma radiation, namely $\mathrm{Al}_{2}\left(\mathrm{SO}_{4}\right)_{3}$, $\mathrm{NH}_{4} \mathrm{Fe}\left(\mathrm{SO}_{4}\right)_{2}$ induced degradation. Degradation of textile wastewater could be done but certain experimental factors i.e molecular structure, effect of oxygen, and $\mathrm{pH}$ can strongly influence the degradation The degradation product that could be detected by HPLC were oxalic acid and succinic acid which less toxic.

\section{REFERENCES}

1. GETOFF, N., Rad. Phys. Chem., 65, 437-446 (2002).

2. SPADARO, J.T, ISABELLE, L. and RENGANATHAN, V., Env. Sci. Technol., 28, 1389-1393 (1994).

3. SOMASIRI, W., RUAN, W., XIUFEN, L. and JIAN, C. Electronic Journal of Environmental Agricultural and Food Chemistry, (2006).

4. MIYATA, T., Liquid Wastes Chemistry, UNDP/IAEA/RCA Regional Training Course on Radiation Technology for Environmental Conservation, JAERI 27 September -8 October (1993). 
5. SPINKS J.W.T., and WOODS, R.J., "An Introduction to Radiation Chemistry", John Wiley \& Sons, $2^{\text {nd }}$ Edition (1976).

6. BAGYO, N.M.A., ARAI, H. and MIYATA, T., Applied Radiation and Isotopes, 48 (2) 175-181 (1997).

7. BAGYO N.M.A., ANDAYANI, W. and SURTIPANTI, S., "RadiationInduced Degradation and Decoloration of Disperse Dyes in Water, Environmental Application of Ionizing Radiation", edited by WILLIAM J. COOPER, RANDY D. CURRY and KEVIN E. O'SHEA, 507-519 (1998).

8. SUMARTONO, A., ANDAYANI, W., SADJIRUN, S. and ARMANU, Pengaruh Iradiasi pada Zat Warna Disperse Antrakuinon (Terasil Blue) Dalam Larutan Air, Risalah Pertemuan Ilmiah Aplikasi Isotop dan Radiasi, Jakarta 13-15 Desember (1994).

9. ANDAYANI, W., BAGYO, A.S., WINARNO, E.K. and WINARNO, H., Pengaruh Iradiasi Gamma pada Zat Warna Maxilon Blue Dalam Air, Risalah Pertemuan Ilmiah Aplikasi Isotop dan Radiasi, Jakarta 18-19 Februari (1998).

10. ANDAYANI, W., and SUMARTONO, A., Majalah Batan, XXXII, (1/2) 37-49 (1999).

11. WINARNO, E.K., BAGYO, N.M.A., ANDAYANI, W., WINARNO, H. and WIDAYAT, E., Penguraian Zat Warna Direct Red 80 Dalam Air dengan Iradiasi Gamma, Prosiding Pertemuan dan Presentasi Ilmiah Teknologi Pengelolaan Limbah I, 10-11 Desember (1997).

12. SUMARTONO, A., LINDU, W.A. and WINARNO, E.K., Indo. J. Chem., 6 (3) 225-230 (2006).

13. BAGYO, A.N.M., LINDU, W.A., WINARNI, H. and WINARNO, E.K., International Journal of Environmentally Conscious Design \& Manufacturing, 12 (1) 21-24 (2004).

14. NICKELSEN, M.G., COOPER, W.J., KURUCZ, C.N. and WAITE, T.D., Env. Sci. \& Tech., 26 (1) 144-151 (1992).

15. SUZUKI, N., NAGAI, T., HOTTA, H. and WASHINO, M., Int. J. Apll. Radiat. Isot., 26 (1975). 